\title{
Janusz Jasiński
}

\section{RETURN OF WOJCIECH KĘTRZYŃSKI TO POLISHNESS}

Słowa kluczowe:

Schlüisselwörter:

Keywords:

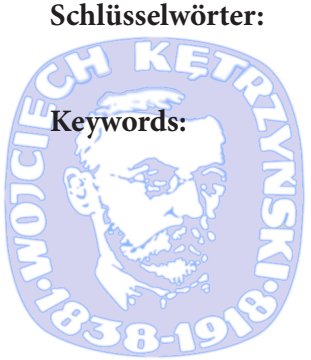

Prusy XIX wiek, Wojciech (Adalbert) Kętrzyński, tożsamość narodowa, biografistyka

Preußen im 19. Jahrhundert, Wojciech (Adalbert) Kętrzyński, Nationale Identität, Biographie

19th century Prussia, Wojciech (Adalbert) Kętrzyński, national identity, biography

I’ve been dealing with Wojciech Kętrzyński since 1967, when I came across a fascicule in the Prussian Privy State Archives (located then in Merseburg, GDR) concerning his participation in the January Uprising and could shed new light on this important event in the life Kętrzyński before he became a great historian ${ }^{1}$. The article was noticed and included in the II edition of Stefan Kieniewicz's preeminent work on the January Uprising ${ }^{2}$. A few years later, I advanced a thesis claiming that Kętrzyński restored his Polishness in an evolutionary way, and not - as he wrote - as a result of his sister's letter in which she revealed that their father's name was Kętrzyński, and so they were Poles, not Winklers - Germans ${ }^{3}$. In 1968, in the Ossolineum Library in Wrocław, I found 5 of his notebooks with his juvenile poetry. At that time, together with Antoni Łukaszewski, retired employee of the Regional State Archives in Olsztyn, we could support the view established in 1970 with new sources. ${ }^{4}$ Since that time, several decades have passed. As it turned out, not

1 J. Jasiński, Wojciech Kętrzyński w powstaniu styczniowym, Komunikaty Mazursko-Warmińskie, (hereafter KMW), 1967, no 1-2, pp. 85-100.

2 S. Kieniewicz, Powstanie styczniowe, ed. II, Warszawa 1983, p. 622.

3 J. Jasiński, Przeobrażenia w świadomości narodowej Wojciecha Kętrzyńskiego, Rocznik Olsztyński, vol. 9, 1970, pp. 11-26.

${ }_{4}$ R. Marchwiński, Sesja naukowa poświęcona Wojciechowi Kętrzyńskiemu, KMW, 1968, no 2, p. 441 (A. Łukaszewski’s report); W. Kętrzyński, Wiersze nieznane, wybrał i odczytał z rękopisów A. Łukaszewski, introduction by A. Łukaszewski and J. Jasiński, Olsztyn 1973, passim; Z. Brocki, Z twórczości poetyckiej Wojciecha Kętrzyńskiego, Dziennik Bałtycki, 1973, no 190 of 12-13 VIII. 
everyone agreed with our thesis ${ }^{5}$, so I decided to revisit Kętrzyński's childhood and teenage years and especially the diary, which he wrote in the twilight of his life. ${ }^{6}$ I have also included the older literature, mostly relating to the history of Lec (now Giżycko) in the mid-nineteenth century. ${ }^{7}$ Oftentimes, scraps of memories from distant past are closer to truth than whose concerning recent years. I experienced it myself when I was writing down the story of my family and my life. ${ }^{8}$ Here is an example from Kętrzyński's life that illustrates this. With 75 years behind him, he tried to evoke his memories of the events of 50 years ago, that is, before the January Uprising 9 . He made then a major mistake, as he wrote that he was arrested in Koenigsberg, when in fact he was arrested for the first time in Olsztyn, and for the second time in Świecie County, but never in the city over Pregolya River. Thus, the memories relating to his latest years should be approached with more caution than those concerning his earlier years. The first publisher of $Z$ dziejów mojej młodości, Tadeusz Czapelski, very accurately noted that 'Kętrzynski describes some important episodes, for example the January Uprising, barely touching upon them, as if in a hurry. But he played a significant role in the unfortunate year $1863 .^{10^{\prime}}$ We can also observe his parsimonious treatment of the Spring of Nations; he was 10-11 years old back then, so he could have remembered a lot. At that time, even the town of Lec was quite busy with its political rallies, elections and smaller or larger social disorders. Perhaps he decided not to mention it at length because it was not directly connected with the main personal thread of his memories concerning the national transformations. Also, I believe he was writing intermittently, distracted by important responsibilities or illnesses.

II

Let us then look at his childhood in the town of Lec through the eyes of Albert Winkler and confront it with other sources. As he wrote, he remembered that it was 'a very Polish town from the beginning', but immediately added: 'it began to pp. 15, 249.

J. Kowalkowski, Badania genealogiczne Wojciecha Kętrzyńskiego (1838-1918), Poznań Wrocław 2002,

6 Ibidem, p. 149.

E. Trincker, Kronika gminy leckiej [giżyckiej] poświęcona ukochanemu miastu w święto trzechsetlecia jego istnienia przez jego duszpasterza ..., superintendenta, Lec, 15 maja 1912, translated by R. Wolski, edition and introduction by G. Białuński in collaboration with J. Sekta, Giżycko 1997; R. Petong, Lötzen vor 50 bis 60 Jahren, Mitteilungen der Litterarischen Gesellschaft, H. 20/21, 1919, pp. 78-79; R. Petong, Lec sprzed półwiecza, in: $Z$ dziejów Leca (Giżycka). Wybór szkiców i źródet, introduction and edition by G. Białuński, G. Jasiński, R. Tomkiewicz, German texts translated by M. Szymańska-Jasińska, Olsztyn 1998, pp. 68-82; publisher’s footnotes (G. Jasiński).

8 J. Jasiński, Czas odległy i bliski. Paczosowie i Jasińscy w XIX i XX wieku, Olsztyn 1998; idem, Migawki z życia mojego, Dąbrówno 2017.

9 W. Kętrzyński, Z młodości, Kronika Powszechna, 1913, no 5, p. 85.

10 T. Czapelski, Rewindykator polskości, Rocznik Zakładu Narodowego im. Ossolińskich, 1927, p. 6. 
lose its national character already then', and this due to German language being introduced into the schools' curriculum ${ }^{11}$. The reader therefore cannot escape the impression that the city almost immediately, that is, already in the middle of the XIX century, became German, while in fact it was a long process that lasted for many decades. For example, in 1872 there were 5049 Poles out of 10185 persons in the Lec parish ${ }^{12}$; in fact, there were even more, since bilinguals were considered Germans as a rule.

Richard Petong decided to illustrate the life of Lec based on the recollections of its most aged inhabitants, mostly 70 -year-olds and even older. Petong's work was published in 1919. Fragments of reminiscences from that time were also submitted by the nearly 80 -year-old director of the Ossolineum Library. Petong's study mentions, among others, the Polish expression recorded by Kętrzyński 'do ryb, do ryb ${ }^{13}$ (to fish, to fish), which the library director repeated in his recollections from the end of the First World War The day-to-day Polishness of Lec was especially visible in age-old customs, mores and religious life, In fact, differences were hardly noticeable between the Lec traditions of Albert's childhood and those of the Masurian villages back then. Petong writes: The Masurian-Polish families preserved a number of customs traced back to the Slavic heritage related to Christian and harvest festivals. After all, by representing their customs, the large Masurian folk community tried to prove their value. Between Christmas and New Year's Day, or even before, the city was swarming with carolers carrying a star, a goat and a horse. ${ }^{14}$ An important role within the tradition was held by the ritual of 'Jutrznia na Gody', Christmas Lauds, which to some extent can be compared with the Catholic Nativity play. Back in 1883, Martin Gerss wrote about it: 'I celebrated the Christmas Lauds only in Polish. Children could read Polish fluently, there was no student who [couldn't] speak Polish. ${ }^{15}$ Wojciech Ketrzyński quoted the old harvest song 'Plon, niesiemy plon' in his book $O$ Mazurach from $1872^{16}$, and it was Petong who also quoted the beginning of it in the original version of 'Plon, niesiem plon. ${ }^{17}$ Kętrzyński mentioned that he wrote down these songs in Orłów, Lec County and in the town itself back in $1871^{18}$. It is known that Wasiański's Masurian cantional enjoyed great popularity; the last edition was published in $1926^{19}$. Presumably, Albert's parents didn't know

11 W. Kętrzyński, Szkice, edition and introduction by A. Wakar, Olsztyn 1980, p. 4.

12 W. Chojnacki, Zbory polsko-ewangelickie w byłych Prusach Wschodnich, Reformacja w Polsce, vol. 12, 1953/1955, [print 1956], p. 336.

13 R. Petong, op. cit., p. 80.

14 R. Petong, Lec sprzed pótwiecza, p. 79.

15 Sprawy Mazur i Warmii w korespondencji Wojciecha Kętrzyńskiego, ed. W. Chojnacki, Wrocław 1952, letter of M. Gerss to Karol Żółkiewski from 20 VII 1883, p. 211.

16 W. Kętrzyński, O Mazurach, ed. 2, edition and introduction by J. Jasiński, Olsztyn 1988, p. 11.

17 R. Petong, Lec sprzed półwiecza, p. 80.

18 W. Kętrzyński, O Mazurach, p. 16.

19 J. Jasiński, J. Małłek, Kancjonał Mazurski. Przedwczoraj, wczoraj, obecnie, Olsztyn 2017, p. 177. 
the cantional, which does not necessarily imply that it was unknown to their children, given their contact with Masurian children and their parents. 'Male youth had the opportunity to frolic outside the cramped apartments in the yards, parcels and open air. There was no peasant farmstead in which any school-age boy would not feel at home; the owners of all the houses and their tenants were also wellknown', Richard Petong writes ${ }^{20}$. Let us set the record straight. It is and established fact that Albert was very interested in books. In 1872, he wrote: "Cantional is a rich and comprehensive collection of church and private compositions, as well as translations ${ }^{21}$. However, one could raise the question whether it was also known in Lec, given the strong presence of German elites living there. The answer is that it was known indeed: the Germans used the German version while the Masurians used Wasiański's version. In 1827, the local protestant Church was restored and consecrated. During the ceremony, the songs performed first came from the German cantional, then the Masurian version was sung in Polish, among them the old anthem 'Ciebie Boga chwatemy', in German: 'Herr Gott, dich loben wir' (lat. Te Deum laudamus) ${ }^{22}$. It is possible that Albert, in addition to accompanying his mother's in the German divine services and participating in them at school ${ }^{23}$, voluntarily joined Masurian children, for example to take part in the mentioned religious ritual of Christmas Lauds. As far as the knowledge of local dialect is concerned, Kętrzyński's slightly forgotten statement from 1876 relating to his childhood is of much importance here: 'I myself remember the days when in almost every home Polish was spoken ${ }^{24}$. How would he know that if not by visiting these homes; inevitably he had to talk using the Masurian dialect not only with peers but also with their parents. Here is another valuable memory of his early years: 'the wet-nurses from my childhood told me stories of it [Sztynort Palace] as if it were a miracle [bold by J.J.] , that it had as many windows as there were holes in a thimble. ${ }^{25} \mathrm{I} \mathrm{im-}$ agine the wet-nurses must have been Masurians who Albert's mother hired because they agreed to a more modest salary than the generally wealthier German women would. Stanisław Krzemiński, the author of Wojciech Kętrzyński’s biography, who probably met him in Lviv, wrote: 'but an instinct of some sort was watching over the young man. The Polish-speaking domestic servants and the Polish environment may have already kindled in the boy his first unconscious desire to resurrect his Polishness [bold by J.J. ${ }^{26}$. More than fifty percent of the Polish people among

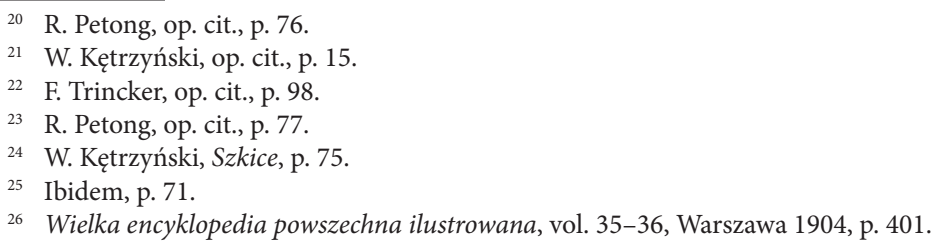


the inhabitants of Lec in the middle of the XIX century is confirmed by Richard Petong:

Most of the petty bourgeoisie was of Masurian-Polish origin, therefore it was very often the case that Polish was considered the native language and the German families, not knowing the dialect, could hardly communicate with the surrounding population, especially with peasants in trade contacts. Before the court, or while dealing with authorities in case of major commercial interests, they had difficulties without an interpreter ${ }^{27}$.

The fact that Albert spoke Masurian dialect and didn't have to learn it, is evidenced by the collection of folk songs that he made ${ }^{28}$. He collected them during his summer stays at pastor August Kiehl's in Orłów, and interestingly, he did that thanks to the encouragement on the part of his friendly German host. Krystyna Korzon, having read through Albert's correspondence, back then a student of the middle school in Rastembork, writes: 'Kiehl's home was dominated by the cult of the regional past; he wrote down the folk songs himself; Elizabeth [daughter] recorded them also, and they were of much interest to the visitors as well. The wise pastor showed Albert the value and the beauty of spontaneous folk poetry. From that time on, Albert started to wander from village to village, busily recording the songs, rhymes and poems he could hear from the local population. Collecting folk songs became a passion of his stays at Orłów in the period of 1855-1859, bringing him the nickname "Landstreicher " (Wanderer)..29 Thus, he began to collect folk songs even before 1856, when he began to study the Polish literary language. It is worth repeating that he learned the Masurian dialect in Lec, his family town. Thanks to this, following the example of Gisevius, he could soon release a collection of Masurian songs, which brought him appreciation throughout Poland and, in addition, an easier identification with the Masurian people in the years to come (although he never forgot about his Kashubian ancestry). Back in 1868, he knew that Gisevius 'collected such [Masurian] songs. ${ }^{30}$

27 R. Petong, op. cit., p. 71.

28 See O. Kolberg, Mazury Pruskie. Z rękopisów opracowali W. Ogrodziński, D. Pawlak, ed. D. Pawlak, Wrocław Poznań 1966, passim, especially p. XXV.

29 K. Korzon, Wojciech Kętrzyński 1838-1918. Zarys biograficzny, Wrocław 1993, p. 31.

30 Dziennik Poznański 1868, no. 237. - Here, it is worth to go back a few years. During the uprising, Wojciech kętrzyński became friends with Kazimierz Szulc, Commissioner of the National Government, to whom he gave his apartment in Koenigsberg in 1863. The two men were brought together by their activities towards independence, but also by their shared historical and ethnographic interests. Szulc titled Kętrzyński 'Dear Mr. Wojciech'. As it is well known, Ketrzyński served a punishment of one year in the Kłodzko fortress, and Szulc spent three years in the Magdeburg prison. For Szulc, Kętrzyński was an authority on Masurian matters. Once he asked him: 'What are the properties of the Prussian-Mazurian language? Is there any collection of songs of the Mazurian people, or do you know some of them by heart? If you do, then please be kind to present them to me together with 
As director of the Ossolineum Library, Kętrzyński made an attempt at assessing the state of Polishness of little Albert from the perspective of more than half a century: 'If I could already speak Polish as a child, I do not know, and I doubt it; however, I understood what was said, which is confirmed by the fact that I liked the company of an old servant who once served under General Kościuszko and loved to tell stories about it, and who did not know German. ${ }^{31}$ Undoubtedly, this Kościuszko soldier could not have been Masurian. I can't imagine curious children, Albert among them, not willing to ask him questions about different episodes of his life, not only the military ones. He probably also spoke Polish with another non-Mazur, 'Mister Dąbrowski', a fan of Napoleon ${ }^{32}$.

III

Let us now discuss Albert's father. The diary shows that he loved him, called him a Pole and a Catholic; as an exception, he had to admit that he was a gendarme, as in case of his hearing before a prosecutor in Berlin. ${ }^{33}$ On the basis of the diary itself, one could only suspect the official service his father went through, since after his death, the half-orphan was taken care of by 'Herfurth, Lieutenant of the gendarmerie: ${ }^{34}$ However, when applying for the position of Professor at the Jagiellonian University in 1870, Kętrzyński wrote: 'my Father was a Prussian official', ${ }^{35}$ which is hardly surprising, because an official is not a gendarme.

Kętrzyński had his reasons to consider his father Polish, given the name, knowledge of the Polish language taken from his home, and because of the Polish coat of arms Cietrzew. These were external, objective conditions. Meanwhile, the following fragment of memoirs testifies about the internal beliefs of his father: 'he liked to tell stories about Poles, about my grandfather and grandmother, about Jezierski who was his guardian [...], sometimes he even hummed to himself 'Jeszcze Polska nie zginęlą; [bold by J.J.], and he said he'd hire a teacher so I could learn Polish, but this never happened. Playing with our hobby-horses, me and my sister always went to Warsaw and Gdansk, yet rarely to Konigsberg ${ }^{36}$. For Kętrzyński,

an explanation of all the properties of the Prussian-Masurian language.' We do not know what answer Kętrzyński gave, but we know that before April 1866 he sent Szulc some 'Masurian songs', for which the recipient thanked him 'heartily' (Zakład Narodowy im. Ossolińskich we Wrocławiu, sygn. manuscript 6225 II (letters of Szulc to Kętrzyński from 1 Jan. 1866 and 6 Apr. 1866).

31 W. Kętrzyński, op. cit., p. 12.

32 Ibidm, p. 11.

33 Anklageschrift im Polen-Prozess 1864, Berlin 1864, p. 15: „Johann Adalbert Winkler von Kętrzyński ist zu Lötzen geboren, Sohn eines Gendarmen, 25 Jahre alt, katholischer Religion”.

34 W. Kętrzyński, op. cit., p. 13.

35 H. Barycz, Wojciecha Kętrzyńskiego starania o katedrę Uniwersytetu Jagiellońskiego, Przegląd Historyczny, 1948, p. 326.

36 W. Kętrzyński, Szkice, pp. 11-12. 
a historian, Gdansk was part of the former Poland, given its historical belonging to the Polish Commonwealth and role as the main city of Royal Prussia. He saw this line of thinking in his father, which is why he placed Gdansk next to Warsaw. In addition, the father could have a lot of stories to tell to his children about the city as the Kashubian capital and the place with which his ancestors were associated.

We are still in Lec; in 1846, Albert's father dies. Year 1848 saw the break of a revolution which is known in Polish historiography as the 'Spring of Nations'. Albert is 10 at the time; mature beyond his years, he understands a lot, and, willing or unwilling, he becomes interested in politics. News reach him about the Polish uprising in Greater Poland and the fear of Russian military intervention in East Prussia ${ }^{37}$; he listens to election debates and hears the rumours of riots in the neighbouring rastemborski (kętrzyński) County ${ }^{38}$. By the years 1848-1849, the rector of Wielkie Sterławki, Marcin Gerss, whom Albert remembered well, becomes strongly involved politically ${ }^{39}$. He briefly mentioned a newspaper, the name of which he did not remember, but which he must have read: 'near us lived Mrs. Umlauf, a widow, who came from the professor's home, whom I often visited; her sons founded a printing house and, in 1848 printed a newspaper. 40 This newspaper was a bilingual weekly published in the Masurian dialect and in German called 'Tygodnik Leczky' - "Lötzener Wochenblatt". It was published and printed by Adolf Umlauf, edited in Polish by teacher, and organist Sgonna; then the edition was taken over by teacher Sauff. The weekly was published since February 2, 1849, only to be discontinued at the beginning of the next year. ${ }^{41}$ Adolf Umlauf graduated in theology, in 1882 and 1883 was rector of the girls' school in Lec, then moved to Lubawskie ${ }^{42}$.

I suppose that at the beginning of the revolution, there was only one political party in Lec - Klub Konstytucyjny (Constitutional Club). As it did not have its own press organ, it published in the liberal 'Königsberger Hartungsche Zeitung.' It shared the newspaper's criticism of the police's omnipotence, while differed from it in its desire to preserve the royal power. For example, it criticized the Berlin's Preussenverein für Constitutionelles Königtum for its plans to recreate the secret police despite its seemingly apt name. However, it also objected to the Koenigsberg's Constitutional Club in its support for the proposal of an Elblag deputy, Juliusz Berends

37 J. Jasiński, Władze i społeczeństwo Prus Wschodnich wobec Rosji i uchodźców polskich w pierwszych tygodniach rewolucji marcowej w 1848 r., in: Kościót-kultura-społeczeństwo. Studia z dziejów średniowiecza i czasów nowożytnych. Profesorowi Stanisławowi Trawkowskiemu w osiemdziesiątą rocznicę urodzin przyjaciele, koledzy, uczniowie, Warszawa 2000, pp. 251-257.

38 Mazury i Warmia 1800-1870. Wybór źródeł, ed. W. Chojnacki, Wrocław 1959, pp. 199-201; J. Jasiński, Wiosna Ludów, in: Historia Pomorza ed. by G. Labuda, vol. III, (1815-1850), part 2, Poznań 1996, pp. $287-288$.

39 W. Kętrzyński, op. cit., p. 153, ,... I know Mr. Giersz since childhood...'

40 Ibidem, p. 11.

41 M. Meyhöfer, Lötzen. Ein ostpreussisches Heimatbuch, Würzburg 1961, p. 274-275 ; W. Chojnacki, Bibliografia polskich druków ewangelickich Ziem Zachodnich i Północny 1530-1939, Warszawa 1966, pos. 2448.

42 E. Trincker, op. cit., p. 142. 
who called the Parliament in Berlin to announce a solemn proclamation that would praise the revolutionary events in the capital of March 18-19, 1848. The Lec Club believed that the monarch was overly humiliated ${ }^{43}$ (let us recall that king Frederick William IV was even forced to take off his hat ('Hut ab') in front of some Poles released from prison). The Club was led by Martin Gerss, who remained faithful to the liberal principles after the revolution was stifled; as a result, he had to leave the position of the rector in Wielkie Sterławki, yet this was not only for political reasons. ${ }^{44}$ According to the democratic 'Neue Königsberger Zeitung', the conservative party had influence in the Lec County even among the workers who built the fortress ${ }^{45}$. While Kętrzyński says nothing about the political direction of 'Tygodnik Leczky', I believe it was conservative. Firstly, if it was to support the liberals, then Martin Gerss would be entrusted with its edition, who spoke Masurian very well, and the newspaper would be named "Tygodni Lecki" instead of 'Leczky'. Secondly, Adolf Umlauf, the publisher, later became a pastor; as a rule, both evangelical and catholic clergy supported the conservative side. Thus, it can be assumed that Albert, who became friends with the Umlaufs, as he left for Potsdam, had rather conservative views, if one can speak of political views in an 11 -year-old at all.

However, his interest in public affairs do not end here. Even before the death of his father, he heard a story from the district doctor Zettnow, a Winklerhof family friend, about a meeting of the Lec notables with the school counsellor of the gąbińskie district. Held at a Lec superintendent's house, the meeting was aimed at introducing German as compulsory language of instruction, obviously at the expense of Polish. What the 7-year-old Albert remembered was:

As the Polish school in Lec was to be closed, a school counsellor came from Gąbin, whose name, unfortunately, I cannot recall [he was Karol August Rättig]; an evening meeting was organized by the then Lec superintendent [Gottlieb Skupch] in his honour, to which several persons from the city were invited, as well as some teachers, among whom there was also present Mr. G. from M. During the meeting Doctor Zettnow, native of Berlin, spoke to the school counsellor expressing his opinion that the destruction of the Polish schools caused harm to the Polish population. The counsellor answered in the following words: "no matter the harm, no matter that the result of the liquidation of the Polish schools will render several generations of the Polish people useless ('dass einige Generationen über Bord geworfen werden'); the thing that matters is that German language and German nationality should become dominant everywhere ${ }^{46}$.

43 Königsberger Hartungsche Zeitung, 1848, no 150 from 28 VI.

44 E. Martuszewski, Marcin Gerss jako nauczyciel (1828-1850), KMW, 1978, no 1, pp. 3-25.

45 Neue Königsberger Zeitung, 1848, No. 183 of 30 XI.

46 W. Kętrzyński, Szkice, pp. 69-70. 
As adult, Kętrzyński must have well remembered the story of Zettnow's, since he first recalled it only in 1876, and then repeated towards the end of life $\mathrm{e}^{47}$. However, I was struck the most by the fact that the meaning of Rättig's statement formulated almost literally by the local doctor I found reiterated in Gisevius's 'Die polnische Sprachfrage ${ }^{48}$. A question may arise here whether the quoted utterance of the counsellor, repeated by Zettnow and heard by the young Albert was really remembered by him after decades, or he may have copied them out of the Ostróda pastor's book. However, the doubt is dispelled by the fact that the Ossolineum Library did not have Gisevius's book back in 1876. Thus, Kętrzyński did not make up Zettnow's words nor did he copy them from Sprachfrage. ${ }^{49}$ The Winklers in fact were friends with the Zettnow family, which is proved by another of Albert's memories, who, leaving Potsdam in 1852 (which will be discussed later), stayed for several weeks at the house of the Lec doctor's family. The fact that Zettnow presented a humanitarian spirit and civic courage, and this independently of current political trends, is also positive evidence of his friend Józef Kętrzyński. This kind of high moral conviction, may have had, however unwittingly, some influence on Albert; undoubtedly, his father shared Zettnow's point of view. This would justify the fact that from all his childhood memories, Albert best remembered the fundamental problem raised by Zettnow concerning the merciless language policy of the Prussian authorities.

\section{IV}

He spent three year in the Potsdam institution for orphaned soldiers' children (1849-1852), which has proved by Krystyna Korzon ${ }^{50}$, which is one year shorter than the period he described in his memoirs ${ }^{51}$. This facility can be compared with the Russian Junker school, educating future officers. It is clear that Albert was taught in the spirit of Prussian patriotism and loyalty to the house of Hohenzollern.

47 Ibidem, pp. 12-13.

48 Die polnische Sprachfrage in Preussen. Eine Zusammenstellung von dahin einschlagenden Aktenstücken und Journalartikeln, Leipzig 1845, p. 185. On policy of Germanisation: „Aehnliches ist überall vorgekommen, wo irgend wohlgesinnte Prediger das ist geradezu rohe, grausame despotische, gewissenlose Verfahren ihrer Schullehrer beim Betrieben des zerstörenden Germanisirungswerks mit Ernst zu tadeln wagten: - die Lehrer kehrten sich nicht daran ; denn der Herr Regierungsrath hatte ja genehmigt - „dass immerhim eine oder ein Paar Generationen zum Heile der kommenden verloren gehen sollten und könnten” [bold by J.J.].

49 Gustav Gisevius was a point of interest for a student of the Lviv University, and Kętrzyński's secretary at the same time, Karol Żółkiewski. Thanks to his efforts, the Die polnische Sprachfrage in Preussen was incorporated into the Ossolineum Library, but only about 1885-1886 (Sprawy Mazur $i$ Warmii, op. cit., passim), yet it is not known how this came about (Letter of Zakład Narodowy im. Ossolińskich in Wrocław to the author from 16 April 2018)

50 K. Korzon, op. cit., pp. 13-14. The author relied on a letter of Kętrzyński’s colleagues from the Wilhelm Ebel town school in Lec, Gustaw Bartel, who reminded the Director of the Ossolineum Library that they were school colleagues in 1852 .

${ }^{51}$ W. Kętrzyński, op. cit., p.17. 
According to the diary, he felt quite well there at first, being a protégé of the institution's supervisor Colonel Courbier, and came into contact with Prince Charles Frederick and count Charles von der Golz. Albert's grandfather and his mother's father was a tenant in the Golzów estate near Susza. The future enemy of Chancellor Bismarck even reached the rank of army captain ${ }^{52}$. In short, the young Winkler seemed to have a great career ahead of him. However, in the silence of his heart, he reproached himself for feeling no exaltation when singing the Prussian national anthem; what is more, he could not consider himself a Prussian patriot because of his second Polish name that he carried. Albert's memory about his Polish name back in Potsdam is of great significance for our discussion, since it constituted an unbroken thread that he took along when leaving Lec. Back then, those were still only bits and pieces, short flashes of memories from a town in Masuria ${ }^{53}$. The bigger problem was the question of faith. At 14, he was told to decide whether he would be Catholic or would join the Evangelical-Augsburg Church. Under the influence of the general climate in the institution as well as some pressure, he was confirmed in the Protestant Church, while not really knowing anything about the Catholic Church. ${ }^{54}$ Perhaps it was the mandatory choice of religion that began to mobilise him to think about the issues of faith and disbelief. As he admitted, at 15 he no longer believed, which he expressed in a short poem:

\title{
Doubt
}

Believe me, above the stars

there is no just God at all.

You hear blind fate as it lures

Anxiety and threatens with severe pain.

There's no love-star shining.

The whole distant world lies dead.

Caught in that immensity, you are falling.

What makes you still keep your faith?5

52 Ibidem, p. 14-15.

53 The contemporary historian of Warmia, Hubert Orłowski, would define this process as 'deremembrance' of memory (see H. Orłowski, Warmia z oddali. Odpominania, Olsztyn 2000.

${ }_{54}$ W. Kętrzyński, op. cit., p. 15.

55 W. Kętrzyński, Z księgi pieśni człowieka niemczonego. Introduction and edition by A. Wakar, Olsztyn 1980, p. 59:

\author{
Zwątpienie \\ Wierz mi, nad gwiazdami \\ Sprawiedliwego wcale nie ma Boga. \\ Ślepy los słyszysz, jak przynęca \\ Zmartwienie i grozi bólem srogim.
}


Losing his faith had a great impact on Albert's life. It was in 1852 that he left Potsdam ${ }^{56}$, and this must have been abrupt, as he did not even warn his mother about it. When he suddenly appeared in Lec, she began to look for a job for him ('... she wanted me to work in some office as a writer.') ${ }^{57}$ Kętrzyński later justified his departure from Potsdam by the death of the Institution's supervisor, a very improbable excuse. In three years, the Prussian state already invested a lot in the future officer of a noble origin and a capable and promising élève, who was even well-established in the high society. The reason for Albert's departure from the institution was the focal point in the studies of Edward Martuszewski some decades ago, but no final conclusion was reached ${ }^{58}$. I believe that Albert was just kicked out of the Institution the moment they discovered that he had lost his faith. Let us remember the close connection of the throne with the altar - the Prussian king was the head of the Protestant Church in his monarchy. In addition, after the suppression of the revolution, years of repressive reaction followed; among others, in response to a resolution of the democratic and liberal deputies in Berlin in 1848, who removed the traditional phrase 'by the grace of God' before the title of the monarch ${ }^{59}$. Thus, Albert could not stay any longer in the Institution. Along his way, as was mentioned before, he stayed with his Zettnow friends, from whom, I believe, he received some moral support ${ }^{60}$.

His critical attitude towards religion continued for a long period, and Kętrzyński began to associate it with exile, with the cursed foreign land, with spiritual loneliness and abandonment:

\author{
In the Foreign Land \\ Woe, a fugitive from this life \\ Persecuted by hardships, \\ I'm standing here alone, abandoned, \\ With waywardness and hatred in my eyes. \\ Around me just a cold heart, \\ Strangers in a strange land,
}

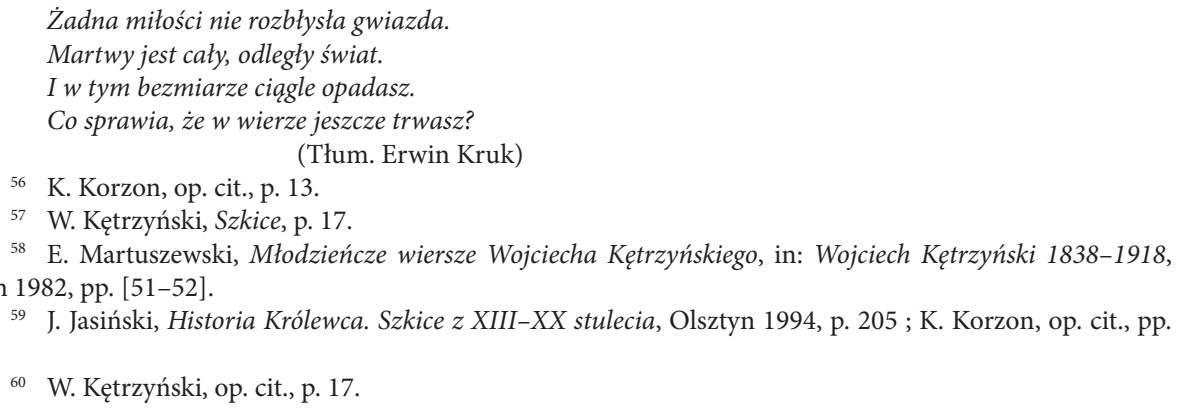

58 E. Martuszewski, Młodzieńcze wiersze Wojciecha Kętrzyńskiego, in: Wojciech Kętrzyński 1838-1918,

${ }^{59}$ J. Jasiński, Historia Królewca. Szkice z XIII-XX stulecia, Olsztyn 1994, p. 205 ; K. Korzon, op. cit., pp.

60 W. Kętrzyński, op. cit., p. 17. Olsztyn 1982, pp. [51-52]. $18-19$. 
And an unfamiliar melody, forcefully

Pushed with the fate's brute hand.

Removed from all the world,

Without a country and without friends,

As child I wandered about the foreign land

And only pain drove me forward.

I was taught to hate early,

Fed with bitter anger,

Early my heart, like a cup,

Was filled with suffering ${ }^{61}$.

Exile in Potsdam, by way of contrast, is associated by him simultaneously with the reminiscence of his native land, of Lec, and with the ashes of his father, to which he must remain faithful.

\section{In the Foreign Land (continued)}

So you can sneer at me

And mock my suffering,

Not filial but just foreign

This heart will remain for you.

The vows I made at my father's grave

Sworn with a pious thought,

I will keep faithfully

While my life lasts.

${ }^{61}$ W. Kętrzyński, Z księgi pieśni, p. 3:

Na obczyźnie

Biada, z tego życia uciekinier

Prześladowany przez los srogi,

Stoję oto sam, opuszczony,

Z krnąbrnością i nienawiścia w oku.

Wokół mnie tylko zimne serca,

Obcy ludzie, obca ziemia,

Obca melodia, która się natrętnie

Wbija przeznaczeń szorstką ręką.

Odepchnięty od całego świata,

Bez ojczyzny i bez przyjaciót,

Dzieckiem błądziłem po obczyźnie

I tylko wielki ból mnie pchał.

Wcześnie uczono mnie nienawiści,

Wcześnie karmiono gorzkim gniewem,

Wcześnie me serce, jakby kielich,

Napetniło się też cierpieniem.

(Transl. Erwin Kruk) 
And even if an evil fate

Erased my solemn words:

Nothing shall frighten me.

My spirit shall find no rest.

Without respite, as blood in the body

Indefatigable is my spirit,

And fate, when it changes,

I will willingly challenge ${ }^{62}$.

Soon, Albert takes an essential step in his religious life as he returns to the faith of his ancestors:

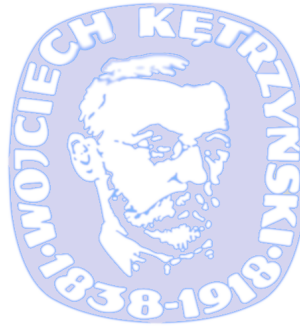

The Bell (excerpts)

I hear the cry of a bell

My eyes are filling with tears

For it summons a lost mocker

To return to the faith of his fathers ${ }^{63}$.

The thoughtful Albert, being already aware of the history of his land, knows that before the reformation Marian devotions were widespread in Mazury, the

62 Na obczyźnie

Możecie więc szydzić ze mnie

I wyśmiewać moje cierpienie,

Nie synowskie zostanie przecie

Dla was, obcy, to oto serce.

Com u grobu mojego ojca

Ślubował z pobożną myślą,

Tego wiernie, pilnie będę strzegł

Aż się moje życie wyciszy.

A choćby przeznaczenie gniewne Przekreśliło uroczyste me słowa:

Nic mnie przerazić nie zdoła.

Mój duch nie zazna spokoju.

Bez wytchnień, jak krew w ciele

Niestrudzony jest mój duch,

I przeznaczeniu, gdy się odwróci,

Śmiało rękawicę rzucę

63 Ibidem, p. 73:

Dzwonek (excerpts)

Styszę dzwonek łkajacy

Mój wzrok napetnia się łzami

Bo wzywa on zbłąanego szyderce

Na powrót do ojców wiary.

(Transl. Erwin Kruk) 
proof of which is the still alive Marian cult in Święta Lipka. He turns to Catholicism, which is evidenced others, the expression 'Madonna', not known among the Protestants who usually called her the Mother of the Lord, the Virgin Mary, the Virgin, the Holy Virgin.

Picture of Madonna (excerpt)

In a deserted niche

A Madonna picture sits

Her face is touched

by the midnight swirling wild.

Madonna with regret in her eyes

Is looking at the realm

Where another faith

Has its temple built.

She remembers with a heavy heart

Those distant days of old

When people in this holy place

Worshipped only her.

Then her figure shone

With gold and precious stones

And the light of silver lamps

Illuminated her ${ }^{64}$.

64 Ibidem, p. 77:

Obraz Madonny (excerpts)

W opustoszałej niszy

Madonny obraz tkwi

Oblicze jej owiewa

północy dziki wicher.

Madonna żalem w oku

Spoglada ku dziedzinie

Gdzie teraz inna wiara

Stawiona ma świątynię.

Wspomina $z$ ciężkim sercem

Odległe owe dni

Gdy lud w tym świętym miejscu

Ja jedyna tylko czcił.

$x * x$

Wtedy jej postać lśniła

Złotem i klejnotami 
The final stage of change in Albert's worldview can be seen in another of his Marian songs:

\section{Prayer}

Blessed virgin, dulcis virgo,

Pay your attention to me,

Listen to the anxious sigh,

The sadness of my songs.

And silence my suffering,

That sank deep in my heart,

And leave me what I was looking for.

Let me find some peace.

Blessed virgin, dulcis virgo,

Yes, since you can, show your will,

Thousands of angels are waiting

To carry out your orders ${ }^{65}$.

It is highly probable that the youthful piety of Kętrzyński was encouraged by, among others, his journeys from Rastemborsk to Święta Lipka. In addition to Catholic pilgrims, he could also meet Masurian folk. His reminiscences of those times, printed in 1876, are very positive:

A światło srebrnych lampek

Świeciło jasno na nia.

(Transl. Andrzej Kamień)

65 Ibidem, p. 81:

Modlitwa

Święta Panienko, dulcis virgo,

Na mnie zwróć Twe spojrzenie,

Wystuchaj niespokojnego westchnienia,

Rzewnego smutku moich pieśni.

I ucisz moje cierpienie,

Które $w$ serce zapadło głęboko,

I zostaw mi to, czegom szukat

Pozwól odnaleźć mi spokój.

Święta Panienko, dulcis virgo,

Tak, Ty to możesz, okaż wole Twoja,

Na spetnienie Twego rozkazu

Czekaja tysiące aniołów.

(Transl. Andrzej Kamień) 
Święta Lipka is famous throughout the whole of Warmia and Mazury region for the miraculous image of the Mother of God, which attracts countless crowds from East Prussia and Poland on the occasion of the indulgence feast of St. Peter and Paul [...] Even nature pays homage to the miraculous [bold by J.J.] and holy place, as the trees in the surrounding forests are said to bend their tops towards Święta Lipka ${ }^{66}$.

Although not being able to acknowledge his belonging to the Catholic Church from the tactical point of view ${ }^{67}$, this time he made an exception, publicly announcing his faith in the miraculous power of the Mother of the Lord.

He went to the Lec town school in the years 1852-1855. The school was headed by a gifted teacher, Dr. Wilhelm Ebel, who spoke Polish well; after many years he had his sermons published (in 1858 he became a priest) in Polish ${ }^{68}$. It is hard to say whether he kept contact with Albert outside the school.

\section{$\mathrm{V}$}

Albert entered the middle school in Rastembork in the spring of 1855 . Antoni Brylowski was the first teacher who he mentions, claiming he was Polish, although he had to know that his name was in fact Anton Brillowski. Obviously, he was Polish to him, because he had a Polish surname, although written in German spelling, and he could speak Polish. However, Albert's suggestion that he had "no contact" with him introduces a clear distance, and even coldness. He was a teacher of history and geography. It is clear that Brylowski presented the history of Poland from the Prussian point of view, which meant, to put it mildly, that it was an unfavourable stance. Apparently, Kętrzyński justified his attitude by the obligation to implement the curriculum provided by the state. He probably didn't really know the real history of the teacher, who graduated from the Catholic middle school in Braniewo, studied history in Koenigsberg, and in 1825-1829 taught history at the Catholic middle school in Chojnice. He studied Kashubian and collaborated with Krzysztof Celestyn Mrongovius. However, in 1828 he married a Protestant, Benwitz, and under her influence, changed his denomination and, after some time, his nationality. As an Evangelist, he had to leave the Catholic school in Chojnice and in 1829 became a teacher in Ras-

${ }_{66}$ W. Kętrzyński, Szkice, pp. 112-114.

67 What Albert meant was that the opponents of his involvement in the Polish matters in Mazury could not use the argument that what he really aimed to do was to spread Catholicism, not Polishness. Because of this, back in 1875, in the wedding document concluded between him and Wincentyna Klińska in Kościerzyna he made sure to state that he was 'of Catholic religion' (J. Kowalkowski, op. cit., p. 158). A canonical transformation to the Catholic Church was made just before his death (Czas, 1918, no 30 ; Dziennik Poznański, 1918, no 18 ; Gazeta Olsztyńska, 1918, no 12 ; Zapiski Towarzystwa Naukowego w Toruniu, 1918, no 6, p. 152).

68 E. Trincker, op. cit., pp. 108-109; Sprawy Mazur i Warmii, op. cit., p. 30 ; G. Jasiński, Słownik duchownych ewangelickich na Mazurach w XIX wieku (1817-1914), Dąbrówno 2016, pp. 112-113. 
tembork, where he joined freemasonry, where from 1848 he held the position of the master of his Lodge. Already in 1833 he made a speech which he later published as a eulogy for the Prussian king Frederick William III ${ }^{69}$. At the beginning of the revolution of 1848, he founded the 'Constitutional Society' with a right-wing and liberal programme. He protested against the absolutism and against the Republicanism ${ }^{70}$, as well as against the unification of Germany (contrary to, for example, the Koenigsberg Democrats led by Johan Jacobi and Ferdinand Gregorovius) ${ }^{71}$. He was engaged in charity (in the Charity Association and the Church Association of Gustav-Adolf) ${ }^{72}$.

According to Kętrzyński, another Pole was 'Kühnast, who was born near Warsaw, where in the Prussian times [New East Prussia] his father was an officer, he had a very beautiful library of Polish classics, supposedly even wrote a thesis on Polish religious songs, yet although he was a great friend of mine, he wouldn"t lend me any of his Polish books, offering all the Greek and Latin ones instead"73. Kühnast was actually born in Fordon near Bydgoszcz ${ }^{74}$. Secondly, not 'supposedly', but actually he published articles on Polish and German hymnology what the diary was mentioned in $1872^{75}$. It should be also added that Kühnast published his articles in Rastembork, even during Albert's stay in the town ${ }^{76}$. Sometimes Kühnast was assisted in his work by a well-known Polish historian of literature and culture, Professor of the University of Warsaw Wackaw Aleksander Maciejowski (1793-1883) 77 . All of these elements, which are: his place of birth near Warsaw (although mistaken), good knowledge of Polish, the Polish book collection at home and his interest in Polish religious songs made Kętrzyński consider Kühnast a Pole. I think the teacher had the opportunity to talk to the student privately, at least about the Masurian cantional. If Kętrzyński did not have his own copy, he could have borrowed it from his colleagues who chose theology as their studies ${ }^{78}$. Kętrzyński adds: '...Kühnast kept his friendliness towards me throughout the later years ${ }^{79}$.

69 A. Bukowski, Florian Ceynowa w gimnazjum chojnickim (1831-1841), Rocznik Gdański, vol. 26, 1967, p. 130, pp. 133-134 ; T. Oracki, Słownik biograficzny Warmii, Mazur i Powiśla w XIX i XX wieku (do 1945), Warszawa 1983, p. 66 ; T. Chrzanowski, Kętrzyn w XIX wieku, in: Kętrzyn. Dzieje miasta, ed. by S. Achremczyka, Kętrzyn 2016, p. 345.

70 Rastenburger Kreisblatt, 1848, no 18 from 29 April; T. Chrzanowski, op. cit., pp. 313-318.

${ }^{71}$ F. Gregorovius, Idea polskości. Dwie księgi martyrologii polskiej, translated by F. Jeziołowicz, introduction and edition by J. Jasiński, Olsztyn 1991, introduction X, XV; J. Jasiński, Historia Królewca, p. 205.

72 Rastenburger Kreisblatt, 1848, № 7, 12, II ; № 8, 19, II ; № 15 of 25 III.

73 W. Kętrzyński, op. cit., p. 21.

74 Allgemeine Deutsche Biographie, Bd. 17, Leipzig 1883, p. 343.

75 W. Kętrzyński, O Mazurach, p. 15.

76 L. Kühnast, Deutsche Kirchenlieder in Polen, I Abt A-D, Abt.: L-Z, Rastenburg 1858, p. 42; L. Kühnast, Die polnischen Übersetzungen deutscher Kirchenlieder, Evangelisches Gemeindeblatt, 1857.

77 K. Korzon, op. cit., pp. 21-22.

78 W. Kętrzyński, Wiersze nieznane, Introduction p. XVI, these were Emil Heschke and Ernst Pohl from Rastembork, Antoni Bolk from Korpel in the Szczycień County, Henryk Schellong from Kalinów, Ełk County and Gustaw Schweiger from Bronów, Węgorzewo County. Of these, only Shellong became a priest (G. Jasiński, Słownik, pp. 299-300).

79 W. Kętrzyński, Szkice, p. 18. 
Kętrzyński had a quite favourable opinion about the school director Frederick Techow, who in 1849 became a member of the Parliament in Berlin. Those times saw numerous conflicts of the democrats and the liberals with the Church officials and the government. Techow had leftist views, for which he was criticised by the Rastembork superintendent Wilhelm Dreist ${ }^{80}$. Re-elected a deputy in 1858 , he still represented the left ${ }^{81}$. In 1862, Techow joined the radical Progressive Party, a movement that the young student Wojciech Winkler-Kętrzyński became attracted by, perhaps thanks to the encouragement on the part of the former director ${ }^{82}$. Meanwhile Techow was absent from school, he was replaced by the only Polish teacher in the school, Jan Marcin Kłupsz ${ }^{83}$, about whom I will mention later.

Kętrzyński did not mention anything about other teachers who did not hide their political views, thus having significant influence on their disciples also after the revolution. While the conservatives did it openly, the democrats and liberals were more careful. For example, teacher of mathematics Jänsch, during the Spring of Nations quite openly claimed that Greater Poland could not be considered part of Germany and Galicia part of Austria. On the contrary, these provinces should become the beginning of the future Poland ${ }^{84}$. After 1849 , he did not change his beliefs. On the other hand, the already mentioned Brylowski as well as Wilhelm Claussen, a right-wing liberal and deputy of the Berlin Parliament ${ }^{85}$, opposed these views. All the while, the middle school youth in the period of the rule of the camarilla, with Winkler already a student there and gradually turning into Kętrzyński, were becoming rebellious. It should suffice to quote the memoirs of Hermann Braun, a later superintendent in Węgorzewo, by any means a supporter of Poland, who was a student in Rastembork just a few years after Kętrzyński: '... the king and Bismarck [he was Prime Minister from 1862] were constantly called names and everybody sympathised with the poor Poles. Also, some colleagues of the last class also kept nattering about it. They argued that the whole German 'nation should unanimously oppose our government and support the Poles. ${ }^{36}$ Thus, Ketrzyński at the beginning of his studies in Rastembork was caught between a rock and a hard place. On the one hand, he joined his German colleagues in the indignation at the reactionary rule of their own state, while on the other, he was constantly reminded about the

80 Neue Königsberger Zeitung, No. 275 of 22 XI.

81 T. Chrzanowski, op. cit., p. 318.

82 W. Kętrzyński, Wiersze nieznane, introduction p. XXIV (over time, Techow moved to the National Liberal Party in 1866) and successfully acted in favour of the germanisation of Polish students (T. Chrzanowski, op. cit., p. 18 ; K. Korzon, op. cit., p. 21)].

${ }^{83}$ Jahresbericht des Königlichen Gymnasium zu Rastenburg, Rastenburg 1859, p. 22.

84 Rastenburger Kreisblatt, 1848, Beilage no 21 from 10 May.

85 On his political activities, see Rastenburger Kreisblatt 1848; in numerous conflicts between the government and society he generally supported the government.

${ }^{86}$ H. Braun, Erzählangen eines Urgrossvaters aus seinem Lebens, Angerburg [1926], p. 104. 
enslaved Poland. According to his own memories, his poem Wann wirst du, schöner Freiheitstag erglühen ${ }^{28}$ proves that he considered himself a German. No doubt he was right. However, the poem requires a commentary. In it, Kętrzyński recognises two German bards of freedom: Ferdinand Freiligrath and Gottfried Kinkel. The first one was a poet, repressed several times for his democratic, even revolutionary activities, and eventually banished to Britain. The latter is a little less known personage. Similarly to Freiligrath, he had to emigrate to London on account of his revolutionary 'scheming'; he belonged to the German Communist Union, which collaborated with the Polish revolutionaries (Henryk Abicht, Ludwik Oborski, Zenon Świętosławski and others). In January 1852, the Central Revolutionary Committee in London printed 3,000 copies of a leaflet written by a German officer Schimmelfenig and distributed it to the major Prussian cities, of which 500 copies went to Koenigsberg. The leaflet was an appeal to the Prussian troops which pointed to the servile attitude of king Frederick William IV towards the Tzar, and was said to have consulted him in order to learn how to oppress his own people. The appeal condemned the three reactive states: Prussia, Russia and Austria. It called the Prussian soldiers to contribute to the fight for the freedom of the oppressed Poland (zur Befreiung des unterdrückten Polens) against Russia, which was the mortal enemy of all peoples. Presumptuous, old German professors and princes were not educated to oppress Poland, but to bring it freedom [debate about Poland in the Frankfurt Parliament in 1849]. German soldiers - said the leaflet - use your weapons for the freedom of the peoples of France, Italy, Poland and Hungary, and you will be welcome there as friends. We repeat: we urge you to fight with Russia ${ }^{88}$. We can safely assume that the above message was also read out in the neighboring Rastembork, known for its intellectual atmosphere. Albert could have obtained it from some of the older students, or even from the democratic teacher himself? The probability of this hypothesis is supported by the extremely fierce tone of Alberts' poem which matches the character of the message in the German Communists' flyer. Their call for freedom for Poland, emphasized in the appeal, was able to touch Albert's heart, who again had the opportunity to remind himself of his father's name. Thus, the poem Polonia Kętrzyński composed with full awareness of his Polishness. The very title of it Polonia stands in opposition to Germany. Secondly, he could have adapted this name from the conspiracy student movement under the same name created in Wroclaw. Lastly, the ending of the song is of great importance:

87 W. Kętrzyński, op. cit., pp. 12-14.

88 Geheimes Staatsarchiv - Preussicher Kulturbesitz Berlin - Dahlem, sign. Abt. Merseburg, Rep. 77, Tit. 500, No. 30, police Directorate in Berlin from 10 Feb. 1852. - even during the January uprising Kinkel published a brochure Polens Auferstehung die Stärke Deutschlands (Resurrection of Poland is the German force). See J. Borejsza, W kręgu wielkich wygnańców (1848-1895), Warszawa 1963, p. 387. 
For a hundred years she lies, defeated by criminals

And yet there has been no knight who could free her.

How many more years this virgin will suffer?

How long will triumph those who brought her misery?

The virgin calls you, the countries of Europe, to take revenge on her Stand up and defend her holy cause with courage! $!^{89}$

It took Ketrzyński long to become mature. An important role in his psychological development was played by the mentioned teacher of mathematics Kłupsz, who 'always surrounded him with care and lent Polish books to him' [bold by - J.J.]. For researchers of Kętrzyński’s biography, he was a quite mysterious figure. Only in 1993 Krystyna Korzon shed some new light on it. Jan Martin Kłupsz was born in 1797 in Poland. During his studies in Wroclaw he belonged to the secret organization called Polonium [bold by - J.J.]. After the organisation was denounced, a trial of Polish students was held in 1821-1822. Kłupsz was expelled from Wroclaw and graduated in Koenigsberg, and eventually was hired in Rastembork in $1824^{90}$. Thus, we can assume that Kłupsz was a real mentor of Albert in matters of his Polishness in the final phase of the process. I don't think the Rastembork school library could have possessed Polish historical works (while these were available in Koenigsberg). During a search in Kętrzyński’s Koenigsberg apartment, the police found his notes about Walerian Łukasiński and Emilia Plater. He explained that they were written during his stay in the Rastembork school ${ }^{91}$. He could only have done it thanks to Kłupsz's books.

We come to 1856, an important year for the present study, when our hero composed Entschluss (Decision), and, as he later explained, it was then when his Polish national consciousness was restored ${ }^{92}$. In his memoirs, he also added (a wellknown fact in the subject literature) that this decision was influenced by his sister's

${ }^{89}$ W. Kętrzyński, op. cit., p. 25:

Już sto lat leży pokonana przez zbrodniarzy

I jeszcze nie znalazt się rycerz, który by ją uwolnit.

Ile lat jeszcze cierpieć ma ta pojmana dziewica?

Czy długo jeszcze będą triumfować ci, co ściagnęli na nia nędzę?

Ta dziewica wzywa was, narody Europy, do pomszczenia jej

Powstańcie i mężnie brońcie jej świętej sprawy!

(Transl. Edward Martuszewski)

90 K. Korzon, op. cit., pp. 22-23.

91 J. Jasiński, Przeobrażenia, op. cit., pp. 12-13.

92 W. Kętrzyński, Z księgi pieśni , pp. 55-56. 
letter. In the letter, on the basis of some personal documents of their father that she found, she comes to the conclusion that they are Polish ${ }^{93}$. Based on these two sources coming from Kętrzyński and his sister, part of the researchers of his biography stated that he underwent a conversion of national identity: a German turned into a Pole, and this was done suddenly. In my opinion, this hypothesis cannot be successfully defended.

Everyone who reads carefully his commentary to the poem Decyzja, introduced, most probably, before the final edition of the 1883 collection, will be able to see clearly that the author regained his national consciousness, or, to be more precise, his original Polishness. And it was not a spontaneous decision, as evidenced by the second part of the song:

Today my song is calling for battle, for a storm of war,

For rebellion and calls, where revenge and hatred

Demand overturning the strong, who took away the land of my fathers

And put the yoke of the Polish head crowned with glory ${ }^{94}$.

Thus, before the final decision, he was very much interested in the history of Poland, and this from the Polish point of view, just as the majority of the nationally conscious Poles did at that time. From his individual ancestry, he shifted towards the national heritage, into which he then incorporated his Masurian background.

His sister's letter probably did empower him to openly admit that he was a Pole, which he in fact started to publicly admit from that time on, first in Rastembork, then in Koenigsberg, and finally in Berlin before the Kammergericht.

In fact, he never succumbed to complete germanisation, neither in Potsdam, nor when, together with his German colleagues, he protested against the tyrants of his state, since what he had constantly on his mid was either his father or the enslaved Poland. His opinion formulated it in 1856 and 1864 of his own national change is closer to the truth than the views he expressed at the end of the First World War. In 1864, he proudly declared: 'I have always felt only Polish, even when I did not understand a syllable in Polish, I always belonged to the Polish people through my father, through my family, through my name ${ }^{95}$. Although one can sense pathos

93 W. Kętrzyński, Szkice, pp. 19-20.

94 Dzisiaj wzywa mnie pieśń do walki, do burzy wojennej, do boju,

Do buntu i do wezwania, tam gdzie zemsta, nienawiść

Każą obalać mocarzy, którzy zabrali mi ziemię, moich ojców

I do jarzma wprzęgneli - ukoronowana chwała - Polski głowę.

(Transl. Erwin Kruk)

95 Der Polen-Prozess im Jahre 1865. Die vollständige historische Darstellung desselben, Berlin 1865, No 53, column 12. 
and exaggeration in this statement, yet his approach back then to the concept of the nation, mainly related to his ancestry, remained in him for life, deepening significantly with time. Contrary to the opinion about his national transformation, Kętrzyński entitled his 1854-1862 poems Aus dem Liederbuch eines Germanisirten, which can be translated as: 'From the book of songs of a man being germanised'; therefore, a man not germanised completely. It is essential to notice this difference. My strong belief in Kętrzyński's evolutionary return to Polishness is strengthened by the argument of Professor Władysław Semkowicz (1878-1949), a Lviv inhabitant, who graduated from and earned his $\mathrm{PhD}$ at the Lviv University. He knew Wojciech Kętrzyński well. In his obituary, Semkowicz said: 'Only after entering the middle school in Rastembork, he was surrounded mainly by the Polish and thus, his Polish national consciousness began to grow slowly in him [bold by J.J.]"96.

In the poem In der Heimat (In the Fatherland) he composed a very significant stanza, repeated as a motto for the only volume of poetry he published in 1883:

Glauben, Sprache konntet ihr mir nehmen,

Doch mein Herz nicht aus dem

Bussen reissen

Und mein Herz blieb immer, immer polnisch ${ }^{97}$.

Much confusion was introduced by Professor Stanisław Helsztyński who wrongly translated the last two verses:

My heart will always be Polish ${ }^{98}$.

This translation was circulated by Edward Serwański in a rather successful biography ${ }^{99}$.After him, many other authors showed interest in Kętrzyński, even the Masurian poet Erwin Kruk in $1980^{100}$. It was Irena Morelowska from Wroclaw who offered a different version:

My heart remains forever Polish ${ }^{101}$.

96 W. Semkowicz, † Wojciech Kętrzyński, Kwartalnik Historyczny, 1918, z. 1, p. 160.

97 Dr Wojciech Kętrzyński, Aus dem Liederbuch eines Germanisirten (1854-1862), Königsberg in Preussen [recte Lviv], 1883. Verlag des Verfassers, title page.

98 W. Chojnacki, Wojciech Kętrzyński, w: Pomorze na progu dziejów najnowszych, ed. by T. Cieślak in collaboration with G. Labuda and S. Hoszowski, Warsaw, 1961. 87, note 36.

99 E. Serwański, Syn odzyskanej ziemi (Wojciech Kętrzyński), Warszawa 1955, p. 50.

${ }_{100}$ W. Kętrzyński, Z księgi pieśni, p. 91.

${ }^{101}$ K. Korzon, op. cit., p. 34. 
To conclude:

Kętrzyński wanted to emphasize in 1856 that his heart was always Polish. Heart means conscience, inner faith, being in contrast to external, acquired German qualities. The above thought resonates strongly with the name of his collection - the author was being germanised, but not completely; his Polishness was recovered - he returned to it; therefore, he never had to acquire it.

\section{Janusz Jasiński, Powrót Wojciecha Kętrzyńskiego do polskości}

\section{Streszczenie}

Ojciec Wojciecha Kętrzyńskiego (1838-1918), Polak pochodzenia kaszubskiego, pełniący w Lecu (Giżycku) obowiązki żandarma, nigdy nie wyparł się swojej polskości. Natomiast matka Wojciecha była rodowitą Niemką i naturalną koleją rzeczy ona miała większy wpływ na wychowanie dziecka. Jednak Wojciech mówił dwoma językami: niemieckim i gwarą mazurską. Literatura naukowa przez długie dziesięciolecia powtarzała, że pod wpływem domu oraz w czasie lat szkolnych spędzonych w Lecu, później w Poczdamie i Rastemborku (Kętrzynie) uległ on całkowitej germanizacji. Dopiero mając 18 lat (1856), dowiedziawszy się z listu siostry, że ojciec był Polakiem, on też podjął decyzję (Entschluss), o przynależności do narodu polskiego. Tymczasem według moich badań proces dochodzenia do świadomości narodowej trwał dość długo. Po pierwsze nigdy nie zapomniał on o polskim rodowodzie ojca, nawet w Poczdamie. Natomiast w Rastemborku zaczytywał się w polskiej literaturze historycznej i to pod jej wpływem postanowił otwarcie przyznać się w 1856 roku do polskości. Zresztą tomik jego młodzieńczej poezji Aus dem Liederbuch eines Germanisierten („Ze śpiewnika pewnego zniemczonego”) potwierdza, że był niemczony. Powolny proces dochodzenia do polskości potwierdzają jego bliscy znajomi, np. lwowski historyk Władysław Semkowicz.

\section{Janusz Jasiński, Wojciech Kętrzyński kehrt nach Polen zurück}

\section{Zusammenfassung}

Der Vater von Wojciech Kętrzyński (1838-1918), der polnisch-kaschubischen Ursprungs war und in Lec (Giżycko) als Gendarm tätig gewesen war, bestritt seine Liebe zu Polen nie. Wojciechs Mutter war jedoch deutsch und besaß natürlich einen größeren Einfluss auf die Erziehung des Kindes. Wojciech wuchs somit zweisprachig auf: Deutsch und Mazurianischer Dialekt. Die Wissenschaft hat schon seit Jahrzehnten klar herausgearbeitet, dass es unter dem Einfluss seines Zuhauses und während der Schulzeit in Lec, später in Potsdam und Rastembork (Kętrzyn), zu einer vollständigen Germanisierung gekommen ist. Erst im Alter von 18 Jahren (1856), als er aus dem Brief seiner Schwester erfuhr, dass sein Vater Pole war, traf er den Entschluss, zur polnischen Nation zu gehören. Meinen Recherchen zufolge hat es aber eine lange Zeit in Anspruch genommen, bis ein nationales Bewusstsein erreicht werden konnte. Erstens vergaß er nie die polnische Abstammung seines Vaters, selbst als er in Potsdam lebte. In Rastemborki dagegen interessierte er sich für die polnische Geschichtsliteratur, und unter dem Einfluss dieser beschloss er 1856, sich offen zu Polen zu bekennen. Außerdem bestätigt der Band seines jugendlichen Gedichtes Aus dem Liederbuch eines Germanisierten, dass er niedergeschlagen wurde. Dass er sich langsam zum „Polen“ entwickelte, wird von seinen engen Freunden wie dem Lemberger Historiker Władysław Semkowicz bestätigt.

Prof. dr hab. Janusz Jasiński (emeritus)

Wojciech Kętrzyński Research Centre in Olsztyn

Partyzantów Str. 87

10-402 Olsztyn 


\section{Primary sources}

Geheimes Staatsarchiv - Preussicher Kulturbesitz Berlin - Dahlem

Abt. Merseburg, Rep. 77, Tit. 500, No. 30.

Zakład Narodowy im. Ossolinskich we Wrocławiu

sygn. manuscript 6225 II: letters of Szulc to Kętrzyński from 1 Jan. 1866 and 6 Apr. 1866.

\section{Secondary sources}

Anklageschrift

1864 Anklageschrift im Polen-Prozess 1864, Berlin.

Die polnische Sprachfrage

1845 Die polnische Sprachfrage in Preussen. Eine Zusammenstellung von dahin einschlagenden Aktenstücken und Journalartikeln, Leipzig.

Der Polen-Prozess im Jahre 1865

1865 Der Polen-Prozess im Jahre 1865. Die vollständige historische Darstellung desselben, Berlin.

Grégorovius Ferdynand
1991 Idea polskości. Dwie ksiegi martyrologii polskiej, translated by F. Jeziołowicz, introduction and edition by J. Jasiński, Olsztyn.

Jahresbericht

1859 Jahresbericht des Königlichen Gymnasium zu Rastenburg, Rastenburg.

Kętrzyński Wojciech

1883 Aus dem Liederbuch eines Germanisirten (1854-1862), Königsberg in Preussen [recte Lviv].

1913 Z młodości, Kronika Powszechna, no 5.

1973 Wiersze nieznane, wybrał i odczytał z rękopisów A. Łukaszewski, introduction by A. Łukaszewski and J. Jasiński, Olsztyn.

1980 Szkice, edition and introduction by A. Wakar, Olsztyn.

1980 Z księgi pieśni człowieka niemczonego. Introduction and edition by A. Wakar, Olsztyn.

1988 O Mazurach, iss. 2, edition and introduction by J. Jasiński, Olsztyn.

Kühnast Ludwig

1858 Deutsche Kirchenlieder in Polen, I Abt. A-D, Abt. L-Z, Rastenburg.

Mazury $i$ Warmia

1959 Mazury i Warmia 1800-1870. Wybór źródeł, ed. W. Chojnacki, Wrocław.

\section{Biographical Lexicons}

$\mathrm{ADB}$

1883 Allgemeine Deutsche Biographie, Bd. 17, Leipzig.

\section{Studies}

Barycz Henryk

1948 Wojciecha Kętrzyńskiego starania o katedrę Uniwersytetu Jagiellońskiego, Przegląd Historyczny, t. 37, pp. 322-342. 
Borejsza Jerzy Wojciech

1963 W kręgu wielkich wygnańców (1848-1895), Warszawa.

Braun H.

1926 Erzählangen eines Urgrossvaters aus seinem Lebens, Angerburg.

Brocki Z.

1973 Z twórczości poetyckiej Wojciecha Kętrzyńskiego, Dziennik Bałtycki, no 190 of 12-13 VIII.

Bukowski Andrzej

1967 Florian Ceynowa w gimnazjum chojnickim (1831-1841), Rocznik Gdański, vol. 26, pp. 73-157.

Chojnacki Władysław

1952 Sprawy Mazur i Warmii w korespondencji Wojciecha Kętrzyńskiego, ed. W. Chojnacki, Wrocław.

1956 Zbory polsko-ewangelickie w bytych Prusach Wschodnich, Reformacja w Polsce, vol. 12, 1953/1955, pp. 303-412.

1961 Wojciech Kętrzyński, in: Pomorze na progu dziejów najnowszych, ed. by T. Cieślak in collaboration with G. Labuda and S. Hoszowski, Warszawa.

1966 Bibliografia polskich druków ewangelickich Ziem Zachodnich i Pótnocny 1530-1939, Warszawa.

Chrzanowski Tomasz

2016 Kętrzyn w XIX wieku, in: Kętrzyn. Dzieje miasta, ed. by S. Achremczyk, Kętrzyn.

Czapelski Tadeusz

1929 Rewindykator polskości, Rocznik Zakładu Narodowego im. Ossolińskich, t. 1, Lwów.

Jàsiński Grzegorz

2016 Słownik duchownych ewangelickich na Mazurach w XIX wieku (1817-1914), Dąbrówno.

Jasiński Janusz

1967 Wojciech Kętrzyński w powstaniu styczniowym, Komunikaty Mazursko-Warmińskie, no 1-2, pp. 85-100.

1970 Przeobrażenia w świadomości narodowej Wojciecha Kętrzyńskiego, Rocznik Olsztyński, vol. 9, pp. 11-26.

1994 Historia Królewca. Szkice z XIII-XX stulecia, Olsztyn.

1996 Wiosna Ludów, in: Historia Pomorza ed. by G. Labuda, vol. III, (1815-1850), part 2, Poznań.

1998 Czas odległy i bliski. Paczosowie i Jasinscy w XIX i XX wieku, Olsztyn.

2000 Władze i społeczeństwo Prus Wschodnich wobec Rosji i uchodźców polskich $w$ pierwszych tygodniach rewolucji marcowej w 1848 r., in: Kościót-kultura-społeczeństwo. Studia z dziejów średniowiecza i czasów nowożytnych. Profesorowi Stanisławowi Trawkowskiemu w osiemdziesiątą rocznicę urodzin przyjaciele, koledzy, uczniowie, Warszawa, pp. 251-257

2017 Migawki z życia mojego, Dąbrówno.

Jasiński Janusz, Małłek Janusz

2017 Kancjonat Mazurski. Przedwczoraj, wczoraj, obecnie, Olsztyn.

Kieniewicz Stefan

1982 Powstanie styczniowe, iss. II, Warszawa.

Kolberg Oskar

1966 Mazury Pruskie. Z rękopisów opracowali W. Ogrodziński, D. Pawlak, ed. D. Pawlak, Wrocław Poznań.

Korzon Krystyna

1993 Wojciech Kętrzyński 1838-1918. Zarys biograficzny, Wrocław.

Kowalkowski Jacek

2002 Badania genealogiczne Wojciecha Kętrzyńskiego (1838-1918), Poznań-Wrocław. 
Kühnast Ludwig

1857 Die polnischen Übersetzungen deutscher Kirchenlieder, Evangelisches Gemeindeblatt.

Marchwiński Roman

1968 Sesja naukowa poświęcona Wojciechowi Kętrzyńskiemu, Komunikaty Mazursko-Warmińskie, no 2, pp. 435-442.

Martuszewski Edward

1978 (1828-1850), Komunikaty Mazursko-Warmińskie, no 1, pp. 3-25.

1982 Młodzieńcze wiersze Wojciecha Kętrzyńskiego, in: Wojciech Kętrzyński 1838-1918, Olsztyn.

Meyhöfer Max

1961 Lötzen. Ein ostpreussisches Heimatbuch, Würzburg.

Oracki Tadeusz

1983 Oracki, Słownik biograficzny Warmii, Mazur i Powiśla w XIX i XX wieku (do 1945), Warszawa.

Orłowski Hubert

2000 Warmia zoddali. Odpominania, Olsztyn.

Petong Richard

1919 Lötzen vor 50 bis 60 Jahren, Mitteilungen der Litterarischen Gesellschaft, H. $20 / 21$.

1998 Lec sprzed pótwiecza, in: Z dziejów Leca (Gizycka). Wybór szkiców i źródeł, introduction and edition by G. Białunski, G. Jasiński, R. Tomkiewicz, German texts translated by M. Szymańska-Jasińskā, Olsztynn.

Semkowicz Władysław

1918 †ojciech Kętrzyński, Kwartalnik Historyczny, 1918, z. 1.

Serwański Wdward

1955 Syn odzyskanej ziemi (Wojciech Kętrzyński), Warszawa.

Trincker Ernes

1997 Kronika gminy leckiej [giżyckiej] poświęcona ukochanemu miastu w święto trzechsetlecia jego istnienia przez jego duszpasterza ..., superintendenta, Lec, 15 maja 1912, translated by Marcin Gerss jako nauczyciel R. Wolski, edition and introduction by G. Białuński in collaboration with J. Sekta, Giżycko.

\section{Journals}

Czas, 1918, no 30 .

Dziennik Poznański : 1868, no. 237; 1918, no 18.

Gazeta Olsztyńska, 1918, no 12.

Königsberger Hartungsche Zeitung, 1848, no 150 from 28 VI.

Neue Königsberger Zeitung, 1848, No. 183 of 30 XI.

Rastenburger Kreisblatt, 1848, № 7, 12, II ; № 8, 19, II ; № 15, 25 III; № 18, 29 IV; № 21, 10 V.

Zapiski Towarzystwa Naukowego w Toruniu, 1918, no 6, p. 152. 